\title{
Clientelism and economic policy: hybrid characteristics of collective action in Greece* $^{*}$
}

\section{Aris Trantidis}

How does clientelism affect policy-making? Can patrons in government discard groups of clients in order to pursue reforms in conditions of crisis? The article argues that clientelism goes beyond the exchange of votes and may permeate organizations with the capacity for collective action such as labour unions. This merger gives rise to a clientelistcollective system that changes both patron-client relations and the context of collective action with important implications for the design of economic policy. As evidence from Greece shows, patrons in government are better off avoiding reforms that deprive their client groups of collective and personal benefits (clientelist bias in policy-making). Labour unions infiltrated by party clients have weak autonomy from the patron party but, operating inside the party network, they can effectively safeguard their access to club goods. Interdependent preferences and organizational linkages between the patron party and its client organizations favour collaboration and co-optation over open confrontation in policy-making processes.

KEYWORDS clientelism, economic policy, Greece, patronage, labour unions, reforms

\footnotetext{
* Earlier version of a paper. Please quote from the article published in the Journal of European Public Policy on 11 November 2015.
} 


\section{Introduction}

The relationship between clientelism and policy-making needs further analysis and empirical substantiation. Recent research has observed a significant association between clientelism and fiscal consolidation under economic crisis (Afonso, Zartaloudis and Papadopoulos 2015) and between clientelism and structural reforms (Trantidis 2014), but the explanatory link between the two phenomena remains under-theorized. While party clients can use their vote to reward or punish their patrons (Pappas 2014: 44-51; Afonso, Zartaloudis and Papadopoulos 2015), politicians facing tough economic conditions may discard some client groups for policies that could secure the system's sustainability and, possibly, broader electoral popularity (Geddes 1994: 95). However, patron-client relations extend beyond the trade-off of votes. Clientelism can permeate labour unions and other

professional groups and blend with typical structures of collective action, generating a hybrid system of interest intermediation. More attention must be paid to the properties of this system - how it differs from both typical clientelism and the conventional interestgroup schema and how it shapes the context of policy preference formation.

This article indicates that the special position of the unions as client groups generates party-union interdependencies and shared interests that limit the degree of government autonomy and favours a policy bias towards protecting the status of unionized client 
groups during a reform process. This is shown in the interplay between PASOK (Panhellenic Socialist Party) and its affiliated unions over a period of 20 years (19852004) in Greece. With a highly clientelist party system ${ }^{1}$ Greece is a 'pilot case' for theory development (Eckstein 2000) and offers a 'tough test' for the resilience of this system when deteriorating macroeconomic imbalances since 1985 exerted strong pressure on Greek governments to consider reform options that could harm the status of unionized party clients, such as privatization, the closure of ailing state-owned companies, lay-offs, and the restructuring of employment terms in the broader public sector. ${ }^{2}$

The article combines a macro-structural study of a clientelist system with the analysis of this institutional setting. In this account, actors respond rationally to the incentives they face, and these incentives are inferred from the empirical context in which they are situated (Boettke et al 2005:290; Pierson 2000:72). This allows research to trace stable relationships connecting social and economic actors in a given setting and infer their recurrent effect on preferences. When some of these features are seen as 'social capital' in a given location (Cf. Tsakalotos and Lyberaki 2002), they are detached from a discussion of institutionally embedded incentives, which could better explain their reproduction and resilience. Historical observations can be clustered in patterns of behaviour and explained by an incentive-based analysis (Bates et al. 1998: 10-13). The analytic narrative does not generate deterministic conclusions (Levi 2002: 122-124) but helps build 'contingent generalizations' (George and Bennett 2005:81, 84) which research can further explore in other case-studies (Gerring 2004:349). 


\section{Clientelism and the context of collective action and policy-making}

Clientelism - the allocation of benefits by political actors (patrons) to political supporters (clients) in return for their support (Piattoni 2001: 4; Stokes 2007: 605) - is seen as 'a vertical, dyadic alliance between people of unequal status, power and resources' (Landé 1977: xx). The typical view is that clients are subjected to hierarchical controls (Scott 1972:92; Eisenstadt and Roniger 1984:48; Medina and Stokes 2007). Part of the literature maintains that clientelism deprives voters of their ability to effectively hold politicians accountable (Stokes 2005). This imbalance persists when party supporters are integrated in networks (Roniger and Güneş-Ayata 1994; Kitschelt and Wilkinson 2007: 8, 17-19). Clientelist networks are not regarded as 'proper groups', but they are seen as 'action-sets' of members who are hierarchically connected to party leadership (Scott 1972: 97; Chubb, 1982:27, 246; Kitschelt, 2000; Wantchekon, 2003). Clients still have heterogeneous and mutually antagonistic preferences. When patrons offer club goods, i.e. a benefit that is shared by its members (Kitschelt and Wilkinson 2007), they are driven not by the clients' organizational capacity, but because they value their clients as voters and campaign resources. Unlike typical interest groups, client groups lack the organizational capacity, autonomy and shared preferences to take collective action beyond what their patrons require or allow. When the literature observed cases of collective action by client groups, these were exceptional cases in which actions were either validated by the patrons themselves (Auyero et al. 2009) or came as protest by small communities that were adequately connected to the outside economy (Shami 2012: 603). 
It is worth exploring, however, how patron-client relationships are redefined when clients are organized in labour unions and other civic or professional associations (LaPalompara 1964; Graziano 1978:297) and how the merger of clientelism with structures of collective action affects the bargaining power and the degree of autonomy of the actors involved. The nature of relations that develop may go beyond the parameters of conventional clientelist exchange. As party clients infiltrate these organizations they gain access to an infrastructure for collective organization that retains its formal autonomy. Clients who enter labour unions or other professional organizations share an occupational status that generates common interests upon which to organize collective action. As a result, they can interact with patrons and the patron party not only in their capacity as individual clients, but also collectively through organizations that promote common policy preferences. Unlike atomized clients in typical patronage networks, they can establish a regular and formal relationship with political power and bargain to secure access to club goods. They can offer coordinated support to individual politicians or the party provided they satisfy their collective demands.

This hybrid system of interest intermediation also differs from the typical interest-group schema in several aspects. Clients who are members of formal organizations are personally tied to patronage networks. Unlike typical interest groups, the autonomy of unions and other formal associations permeated by clientelist ties is weakened by their interpersonal relation to patrons. While organized clients obtain the capacity for collective action, typical patronage controls maintain personal power asymmetry and hierarchy. Accountability, however, is strengthened by the symbiotic relationship between patrons 
and the party leadership, as they both depend on the electoral success of the patron party and its access to power. For patrons, clientelism serves as a solution to the problems of party organization and cohesion; for clients, electoral success secures access to selective benefits, both as individual clients and as members of the politically affiliated client group. As a result, the clientelist-collective system shares elements from both typical interest-group activity and the typical patron-client framework but exhibits idiosyncrasies, as summarized in table 1 .

Table 1: Distinct properties of typical clients, organized client groups and non-client groups

\begin{tabular}{|c|c|c|c|}
\hline & Typical clients & Organized client groups & Typical organized groups \\
\hline Source of & \multirow[t]{4}{*}{ Clientelist exchange } & Clientelist exchange and & Occupational or other \\
\hline association & & occupational and social & affiliation in a formal \\
\hline with political & & affiliation in a formal & organization \\
\hline power & & organization & \\
\hline Demand from & Regular or one-off access to & Regular access to resources as & Regular or one-off access to \\
\hline \multirow[t]{7}{*}{ political power } & resources as 'private goods' & 'private goods' through typical & 'club goods' through \\
\hline & through typical clientelist & clientelist exchange, and & collective action, which \\
\hline & exchange & access to 'club goods' for the & includes public advocacy and \\
\hline & & group through collective & lobbying, and possibly' \\
\hline & & action & explicit or implicit agreement \\
\hline & & & on particular issues (one-off or \\
\hline & & & repeated) \\
\hline Supply to & Individual engagement in & Individual and collective & At times, political or policy \\
\hline
\end{tabular}




\begin{tabular}{|c|c|c|c|}
\hline \multirow[t]{8}{*}{ political power } & political activism, direct & political activism, direct & endorsements depending on \\
\hline & involvement in political & involvement in political & the type of organization, \\
\hline & campaign, public & campaign, public & or/and financial support \\
\hline & demonstration of political & demonstration of political & \\
\hline & affiliation & affiliation as clients; at times, & \\
\hline & & political or policy & \\
\hline & & endorsements as collective & \\
\hline & & organization & \\
\hline Organizational & No, unless requested and & Yes, through typical collective & Yes, through typical collective \\
\hline capacity & directed by the patron & action and through party- & action \\
\hline & & affiliated political activism & \\
\hline \multirow[t]{5}{*}{ Preferences } & Interdependency with patrons & Interdependency with the & Independence; preference may \\
\hline & & patron party as groups of & coincide or intersect with \\
\hline & & clients, which affects the & political parties or the \\
\hline & & configuration of the & government \\
\hline & & organization's preferences & \\
\hline \multirow[t]{6}{*}{ Organizational } & No & Limited because of members' & Yes: occasional formal or \\
\hline & & clientelist ties to the party, & informal associations with \\
\hline & & creating interdependent policy & political agents may be built, \\
\hline & & preferences & preserved or broken on the \\
\hline & & & basis of convergent or \\
\hline & & & divergent preferences \\
\hline \multirow[t]{6}{*}{ Bargaining } & Limited because of collective & Considerable thanks to & Varies depending on \\
\hline & action problems yet clientelist & organizational capacity and the & organizational capacity, \\
\hline & networks are valuable to & significance of the group as & lobbying resources (including \\
\hline & patrons & political resource for the party & media access and money) and \\
\hline & & leadership and patron & scope for shifting alliances \\
\hline & & politicians; yet constrained by & \\
\hline
\end{tabular}


the cost of defection for

individual clients and by co-

optation tactics by the central

party targeting clients

The special properties of this clientelist-collective system are not fully captured by analytical frameworks that neglect the context-specific nature of policy-related bargaining. Typical and, quite often, formal analysis assumes that interest groups and the government have considerable autonomy from one another in terms of preferences and bargaining capacity, and that outcomes are largely determined by relative inter-group power (Krueger 1974; Becker 1983; Alesina and Drazen 1991; Schamis 1999). In the context of clientelism, however, the presumption of autonomy underrates the overlapping roles that emerge inside the broader party-client nexus: organized clients are both members of the organized group and party clients, union leaders are also senior party cadres, while party politicians are both policymakers and the patrons of these client groups. This symbiotic relationship - built upon the long-term exchange of mutual personal and collective benefits - makes the pattern of collective action in a clientelist system more intricate in terms of preference formation and the source of bargaining power. Benefit-distribution is here a process internal to the broader party-client network. Patron-client relationships strengthen the value patrons place in the collective demands of their clients who are situated at the heart of the clientelist network. Patrons are better off tackling any policy grievances by these groups with a view to a mutually accommodating settlement in order to avoid losses in party cohesion and support. Clientelist linkages also moderate the way labour unions 
articulate policy preferences and claim collective goals from decision-makers who are at the same time their patrons. Patrons can use selective patronage benefits to persuade union leaders to adopt a more lenient stance towards their policies, especially unionists with aspirations to enter central politics.

The impact of clientelist ties on policy-making and collective action is comparable but not identical to the ideological-partisan linkage between trade unions and social democratic political parties. Although there are strong incentives for policy alignment in both cases, reciprocity in the clientelist-partisan linkage is both personal and group-level, largely dependent on the provision of both club goods and private-clientelist goods. The distinct microfoundations of reciprocity in the clientelist-partisan linkage have a different impact on the nature of policy claims and the source of the unions' bargaining strength and, in the broader context of inter-party competition, skew policy-making differently.

First, both the nature of policy concessions that client groups ask and the nature of compensation that government must offer, once reforms are under way, are different. In Sweden, for instance, economic policies since the 1970s distanced the social democrats from the trade unions but informal ties were maintained thanks to compensatory concessions to private sector workers that involved welfare and retraining policies (Cf. Upchurch et al. 2009: 9). In the UK, the clash between the Labour Party and the trade unions in the late 1970s primarily regarded wages (Minkin 1992). By contrast, claims in a clientelist system, where labour unions primarily consist of broader public sector employees, revolve around the provision of special privileges that distinguish these 
employees from private-sector workers (creating dual working standards). Similarly, compensation needs not involve comprehensive welfare and training opportunities for all employees. but it has to protect, in sight of restructuring and privatization policies, the privileges broader public sector employees enjoy and the turf for individual favouritism.

Second, because clients in the broader state sector are animated by specific clientelist benefits and not so much by general concessions offered to all workers in the private and public sector, they are less keen to object to general policies towards fiscal consolidation and structural reforms, provided that their privileges both as individuals and organized groups are preserved. Labour union militancy is discouraged thanks to patron-client ties connecting union members, unionists and the party. On the other side, given the different nature of concessions at stake, clientelist patrons do not face a fierce dilemma between implementing reforms generally restricting welfare and distribution but losing the support of the unions, on the one hand, or refusing to reform the welfare state to keep the unions as allies but risking losing voters, on the other (Kitschelt 2004: 133). The kind of dilemma clientelist parties face is about preserving special benefits to core supporters under economic hard times, which requires a tailored-made approach to the design of reforms.

Third, although in the case of the UK, the unions' demands over wages came to be seen by the Labour Party's leadership as an electoral liability (Mcllroy 2002) while in most social democratic settings unions and parties preserved some organizational and sociological ties (Jacoby and Behrens 2014), in the clientelist setting, there are stronger incentives that foster political alignment on both interpersonal and group level. Client unions and the 
patron party have stronger interdependencies that make detachment too costly in the context of inter-party competition. A government party that withdraws the supply of club goods to a client group will risk its ties with that group and could undermine the cohesion and vitality of its campaign support network. Unionists, on their side, should not overlook their role as intermediaries in the patronage network. Hierarchy and control over members of the broader clientelist network limit the scope for client unionists to express discontent against their host political party. As a result, interpersonal linkages, preference interdependencies and the distinct source of bargaining power have important implications for the type of policies the patron party must preferably adopt when in government:

1) When economic reforms have to be implemented, the government will be better off adjusting its reforms to protect patronage supply to its client groups in order to avoid within-party clashes and defections (policy bias in favour of preserving clientelist supply).

2) The above-mentioned concessions (collaboration) and the co-optation of unionists inside the broader clientelist network can prevent confrontation between the patron party and its affiliated unions during a general programme of economic adjustment.

As the table below illustrates, a patron party in government $(\mathrm{G})$ has the options of either ignoring the unions or compromising on its policy to avoid confrontation with the unions. Unions inhabited by client groups (U) have the options of confronting the government openly or showing complacency. In a clientelist system, for both players, option A 
(ignore, confrontation) leads to mutual losses: a clash will undermine the party's cohesion and mobilization capacity and possibly bring electoral defeat that will equally jeopardize the clients' access to private and club goods. A patron party in government will be better off implementing a policy agenda that would cause the least possible damage to the party's cohesion. For the party, compromise with the unions makes sense as it expects that they will reciprocate with a moderate level of protest against general reform policies. For the unions, a complacent stance towards the government is the preferred option insofar as the government is sensitive to their demands as a client group and adjusts its economic policy to protect their core interests.

Table 2: Strategic interactions between government and unions in a clientelist system

\begin{tabular}{|l|l|l|}
\hline \multirow{2}{*}{} & \multicolumn{2}{|l|}{ Patron party in government $(\mathrm{G})$} \\
\cline { 2 - 3 } & Ignore & Compromise \\
\hline
\end{tabular}




\begin{tabular}{|c|c|c|c|}
\hline 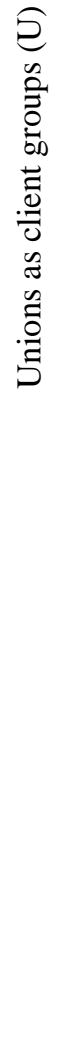 & Confrontation & $\begin{array}{l}\text { A. Bilateral losses } \\
\text { U: Loss in policy } \\
\text { preferences } \\
\text { and damage to } \\
\text { special party ties } \\
\text { G: Policy preferences } \\
\text { attained but damage to its } \\
\text { ties to the unions with } \\
\text { implications for party } \\
\text { cohesion and } \\
\text { mobilization capacity }\end{array}$ & 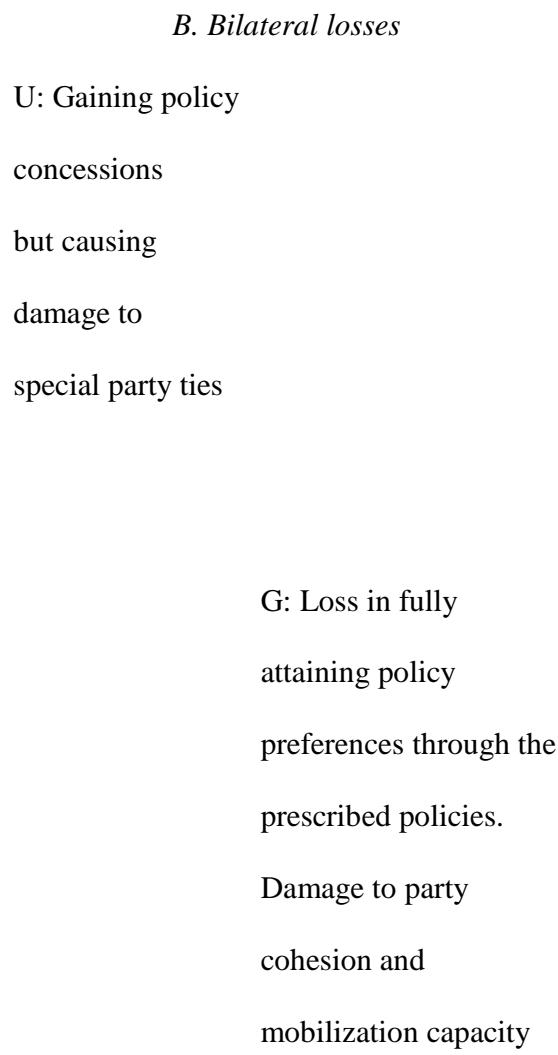 \\
\hline & Complacency & $\begin{array}{l}\text { C. Bilateral losses } \\
\text { U: Loss in policy } \\
\text { preferences, tension } \\
\text { among union members } \\
\text { over complacency } \\
\text { with government policy } \\
\text { G: Policy preferences } \\
\text { attained. Maintaining } \\
\text { social peace, but possible } \\
\text { losses of clients with } \\
\text { implications for party } \\
\text { cohesion and strong } \\
\text { mobilization capacity }\end{array}$ & 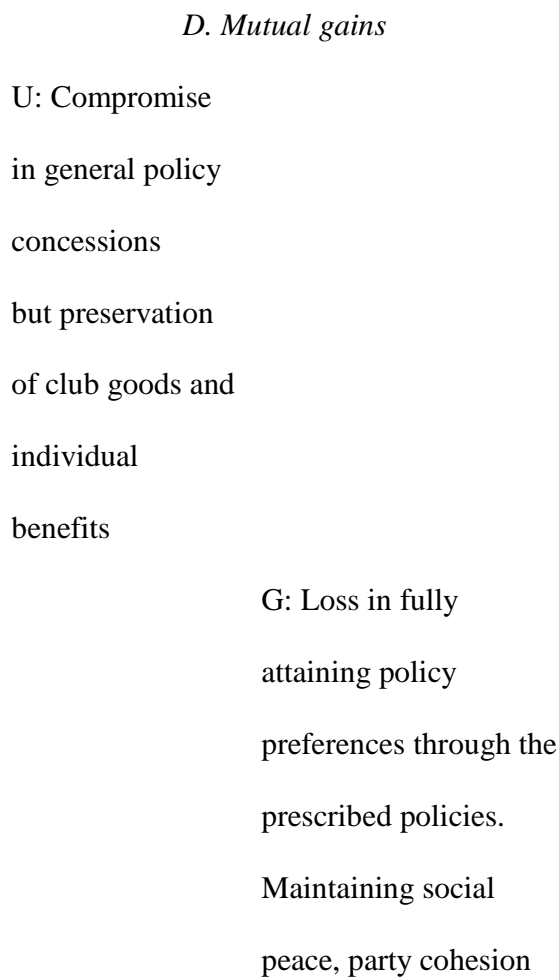 \\
\hline
\end{tabular}




\begin{tabular}{|c|c|c|c|}
\hline & & and strong \\
& & mobilization capacity \\
\hline
\end{tabular}

\section{The clientelist system and its policy implications in Greece}

In Greece, patron-client relationships infiltrated labour unions and redefined their relationship with political power. Following the fall of the military junta in 1974, centreright New Democracy and the socialist PASOK (Panhellenic Socialist Party) massively appointed party clients in the broader public sector, which included the state monopolies in electricity, telecommunications, transport, water and sewage, ports, and radio and television as well as many other commercial enterprises in petrol, defence, shipyards and cement. By the mid-1980s PASOK had developed the strongest client network among the employees of the broader public sector. ${ }^{3}$ Through its sectoral organizations (kladikes), it came to control most labour unions and two main umbrella labour-union associations: the Confederation of Civil Servants (ADEDY) that represented public administration employees and the General Confederation of Greek Workers (GSEE) that represented the unions of the private sector and the state-owned sector of the economy (Lyrintzis 1984; Spourdalakis 1988; Sotiropoulos, 1996; Lavdas 2005; Lyrintzis, 2005; Matsaganis 2007; Pappas, 2009). Union members in the broader public sector could claim both individual favours as clients and collective goods as a group, such as wages higher than the private sector, generous pension schemes, early retirement options, extra benefits and holidays. At the same time, inside the party's affiliated labour organizations, 'free-riding' behaviour 
and dissent could be easily identified (Sotiropoulos 1996: 61). PASOK's leader Andreas Papandreou kept a tight grip on the party's labour organizations by frequently expelling leaders whose behaviour showed signs of factionalism and autonomy. This tactic sent a message to PASOK's union leaders that their career inside the party network was dependent on the endorsement of the party leadership.

This direction of the labour movement can be situated in the broader 'parentela pluralism' framework of state-society relations in Greece (Pagoulatos 2003: 161-167) where various associations direct their demands to the government party. This structure is highly fragmented and therefore, less capable of conducting a broader social dialogue on general policies (See 'disjointed corporatism' by Lavdas 2005). Nevertheless, despite their fragmentation, the unions - largely inhabited by broader public sector employees - were integrated in centralized party machines (Lyrintzis 1984; Mavrogordatos 1997) and formed part of a broader party-clientelist network. Clientelist association with political power created 'unity in fragmentation' under a set of incentives and informal norms governing the provision of sector-specific 'club' benefits. This pattern of collective organization and interest intermediation created a recurrent policy bias towards the supply and preservation of club goods to client groups. The distinct impact on the design of economic policy in Greece is noticeable in the period between the mid-1980s and the mid2000s, during which macroeconomic imbalances and increasing institutional pressures from the European Union (EU) pushed consecutive Greek governments to launch economic reforms. Among the policy options available, structural reforms in the broader public sector and the privatization of state-owned companies were key policies 
recommended by international organizations (European Commission 1998: 13; 2000: 31; OECD 2001: $9,12,31,84,114,116)$ as part of fiscal stabilization programmes and in response to EU law on market liberalization, state aid and competition (Clifton et al. 2003; Pagoulatos 2005: 360). These policies, however, threatened to considerably harm the status of PASOK's unionized clients and, in the following years, tested the relationship between party leadership and the labour unions of the broader public sector.

The literature covering PASOK's reform policies during this period has focused on episodes of confrontation between the government and the labour unions which had initially divergent preferences over specific reform proposals and effectively blocked reform efforts (Pagoulatos 2003; Lavdas 2005; Tinios 2005; Pelagidis and Mitsopoulos 2006; 2011; Featherstone and Papadimitriou 2008). Here the interaction between unions and the government is couched in the typical language of interest groups versus the government. However, if labour unions acted as 'veto-players' that blocked deep-cutting structural reforms, the source of the unions' remarkably strong bargaining power remains theoretically and empirically under-explored. It is puzzling how these groups could hinder policy initiatives given the electoral success and parliamentary majority of the selfproclaimed 'modernizing' government of Prime Minister Simitis (1995-2004). At the same time, Greece came under strong pressures to implement economic reforms, most prominently, binding EU Directives, mechanisms of policy surveillance, and the urgent need to fix its finances to avoid exclusion from the Eurozone and a loss of creditworthiness. Entry to the European Monetary Union (EMU) was an important benchmark for the Simitis government but the Maastricht criteria and the Stability Pact 
allowed it some scope to design its policy mix. Focusing on confrontation episodes does not disclose important information about how the party-union linkage shaped PASOK's overall mix of economic policy and pre-empted further clashes throughout the period in which PASOK was under consistent pressure to reform the Greek economy (1985-80 and 1993-2004).

The overview of economic policy under PASOK and of party-union relations inside PASOK's broader support network offers better insight into the workings of the clientelist system and its impact on policy-making. We can distinguish variations with regard to PASOK's ties with the unions and its choice of policies: open confrontation, coordination with co-optation and contained confrontation. In each pattern we observe the dynamic interaction between PASOK's policies and the relationship between the party and its affiliated unions. Open confrontation between the party and leading party unionists led to mutual losses when in 1985 the re-elected PASOK government responded to a balance of payment crisis with a wage freeze and austerity measures, causing a rift inside the labour union movement. PASOK ultimately abandoned its programme earlier than announced and sought to restore its ties with the labour unions in the run-up to the 1989 election. Returning to power in 1993 PASOK excluded full privatization from its stabilization programme and abstained from implementing comprehensive structural reforms that could harm the status of the unionized employees of the broader public sector (collaboration with co-optation). Policy adaptation by PASOK did not prevent occasional outbursts of dissent over specific policy reforms from party unionists but the scale of their reactions was constrained to avoid undermining PASOK's cohesion (contained confrontation). 
Open confrontation (1985-1987)

Chronic problems of the Greek economy led to a current account crisis in 1985 soon after the general election. The re-elected PASOK government announced a stabilization programme with a general wage freeze and rising taxes together with currency devaluation. The programme, however, excluded privatization, market deregulation, the closure of ailing state-owned companies and reductions in the size of state sector employment (OECD 1987: 20; OECD 1992: 182-3), which would have hit public sector employees. These groups were spared from permanent losses in their status but, just as workers in the private sector, they suffered income losses due to the wage freeze under a double digit inflation. The sudden announcement of austerity came as a shock to the labour unions whose members and leaders expected PASOK to meet its pre-electoral pledge for a generous wage policy. A section of PASOK's loyal unionists reacted to PASOK's stabilization, defected from the party organization and aligned with Communist Party unionists in an attempt to take control of the GSEE. The government appointed compliant unionists in their place. However, tensions inside the PASOK support basis and growing public dissatisfaction with austerity led Prime Minister Andreas Papandreou to end the stabilization programme earlier than scheduled. PASOK relaxed its fiscal policy and resumed patronage appointments before the 1989 election. ${ }^{4}$ PASOK wanted to restore and strengthen its alliance with these groups in view of the coming general election. PASOK's unionists realigned with the party to preserve their access to both individual privileges and 'club goods'. Despite the policy U-turn, the confrontation between PASOK 
and its unionists led to mutual losses and contributed to PASOK's electoral defeat and the election of a government much less attached to the unions. This clash offered a useful lesson for ensuing PASOK governments about the politically optimal design of economic policy from the perspective of a patron party and suggested that collaboration is the optimal strategy in designing economic reform (As in table 2 above).

Coordination with co-optation (1993-2000)

Despite its pre-electoral commitments to abandon fiscal austerity, PASOK returning to power in 1993 pursued fiscal consolidation with a combination of higher taxes and tight monetary policy. It also halted the privatization programme which the previous government had announced. In 1995, the newly elected Prime Minister Costas Simitis proclaimed the desire to secure Greece's entry to the EMU by 1999 . His policy heavily relied on direct taxes and implemented gradual and relatively mild structural reforms in the labour market and the pension system. Most of his economic policies spread the fiscal cost of economic adjustment across the population while protecting the employment status of the unionized employees of the broader public sector (Table 3). The nature of the economic adjustment was such that it caused, for the most part, mild reactions from the politically-affiliated labour unions. However, the prospect of privatization, particularly of the utility companies in telecommunications, electricity and water supply, became a constant source of concern for public sector employees and their unions. To prevent serious reactions, the government reassured that only minority shares would be sold through flotation while the management of the public utilities companies would stay in the 
hands of the state. These enterprises were also protected from competition through informal barriers that essentially prevented the entry of competitors in the same markets (OECD 2001:16, 30 and 95). The employees of these corporations secured permanent tenure and generous retirement benefits and pension plans. In addition, the government offered part of the privatization proceeds to the staff's social security funds (Börsch-Supan and Tinios 2001: 404-5). Older employees were also offered the option of early retirement. For the remaining employees, average wages in public enterprises grew faster than wages in the private sector. New employees were hired under different employment terms, often as temporary contract workers or trainees, which allowed the companies' management some flexibility in organizing their workforce. This 'dualism' in employment terms between a highly protected old guard of employees and new employees with largely fragmented employment terms was a clear indication of the way the government sought to modernize public sector enterprises without undermining the ties with its unionized clients.

Table 3: Pattern of economic adjustment in Greece during the second PASOK government (1993-2004) 
- $\quad$ Rising taxation (both direct and indirect)

- Currency devaluation (in 1998)

- $\quad$ Tight monetary policy (1993-1998) affecting export industries

- $\quad$ Limited reform of public enterprises and organizations

- High tax burden of employment and high national security contributions

- Failure to cut subsidies to ailing public sector enterprises (Olympic Airways, state television, railways)

- Wage restraint in the private sector (19972000)

- Increase in the bills of public utility companies

- Increased public borrowing both nominally and as a percentage of GDP

- Assumption by the government of the debt of state-owned banks, agricultural cooperatives and public corporations (mainly through state guarantees
- $\quad$ Subsidies to pension funds

- Subsidies to deficit-running public enterprises and their pension funds

- Failure to modernize or privatize deficitrunning enterprises

- Indirect protectionism of the monopoly status of government-controlled corporations (in violation of EC law)

- $\quad$ Privileged terms of employment (wage benefits, early retirement, retirement bonus for public sector employees

- Generous retirement schemes in modernization plans for several stateowned enterprises

- Fiscal benefits to public sector employees in the form of overtime payment, compensation for extracurricular activities, such as participation in various committees and travelling expenses

Party unionists declared their opposition to any reform plans that could negatively affect the status of their members, such as the full-scale privatization of state-owned companies. At the same time, they valued the ties they had cultivated inside the party network and refrained from reacting strongly against the government's stabilization programme. Both 
party unionists and party politicians shared an interest in PASOK's electoral success. Confrontation was kept at bay to avoid further escalation that could hurt the party unity and undermine PASOK's chances for re-election. Overall, informal clientelist ties connecting ministers, managers and unionists in the broader public sector limited the scope of reforms in the broader public sector (Spanou 2008: 161).

These party-union linkages also helped tone down the scale and nature of reactions over specific policy measures. Engagement with PASOK gave client employees the opportunity to enjoy extra benefits and good work placements in the broader public sector and offered unionists the prospect of a career in central politics. This pattern of policy coordination and co-optation was manifested in the small scale of the rallies and protests organized by the unions despite the prolonged austerity programme (Vima, 3 November 1996; Kathimerini, 1 July 2001). A Social Pact was signed in 1997, which committed unions to wage moderation and social dialogue in return for important concessions in employment law. The unions' mild response to government policies was unprecedented given the prior history of labour activism in Greece. ${ }^{5}$ However, the relationship between the government and its affiliated unionists remained delicate and depended on mutual interest accommodation. In this context, party unionists had to keep a delicate balance between acting as labour representatives and conforming to the role of party cadres who were expected to support government policy. A statement by PASOK's union leader epitomizes this relationship: 
'I have never hidden the fact that I belong to PASOK. Nor am I hiding the fact that I have supported, I do support and will continue to support President Simitis. Of course, this does not mean that I will not react if the government attempts to hurt our acquired rights' (Vima, 5 April 1998, emphasis added).

\section{Contained confrontation (2001-2002)}

Despite efforts for policy co-ordination and co-optation, the PASOK government did not avoid confrontation with the labour unions over specific policy initiatives. The full sale of a middle-sized bank, Ioniki, in 1998 tested the relationship between PASOK and its affiliated unions. Although the government reassured the employees that the new terms of employment would prevent future lay-offs, PASOK-affiliated unionists outside this bank saw the privatization as a breach of PASOK's policy commitments (Nea, 12 May 1998). At the same time, criticism inside the Cabinet targeted the way the Ministry of the Economy handled the union's reactions (Nea, 1 June 1996). As a way out, the government presented the full sale of Ioniki as an isolated case and rejected proposals for broader structural reforms and full privatizations in an effort to appease the unions and prevent general unrest (Nea, 16 March 1998).

A second and most serious round of labour unrest broke up in 2002 in reaction to proposals to reform the pension system that would have changed several of the terms of retirement for public and private sector employees. The leaders of GSEE and ADEDY, who were also senior PASOK members, rebelled against the reform plan with a scale of 
public protests that demonstrated clearly that these unions had retained a solid mobilization capacity. The protests forced the government to pass a moderate reform of the pension system (Matsaganis 2002). Several PASOK's unionists sought to reinstate their role as intermediaries between their members and the party and became overtly critical of the government's economic policy. ${ }^{6}$ In response, Prime Minister Simitis cancelled a number of scheduled reforms and called an early party conference in an attempt to reconcile with the unions and elicit a vote of confidence from numerous party factions. In the run-up to the conference, a generous 'social package' of welfare policies and wage increases in the public sector were announced. At the conference, party unionists expressed concerns about the direction of government policy but did not challenge Simitis as the party leader. Party unity was the recurrent slogan of the conference, echoing the shared desire of the party base and the affiliated unionists to keep PASOK in power. ${ }^{7}$ Prime Minister Simitis comfortably won the conference ballot and received public reassurances from the party's leading unionists in support of PASOK's cohesion. These episodes were useful in reconfirming that compromise between the government and the unions was the optimal strategic choice for both sides, congruent with the lessons of their previous confrontation in 1985 (As table 2 shows).

The three patterns of government-unions interactions (Table 4) reveal the idiosyncrasies of policy-making and collective action in Greece's clientelist system in view of mutual commitments and shared interests by political patrons and their client groups. PASOK's macroeconomic stabilization did not shy away from unpopular measures such as increasing taxation, ${ }^{8}$ but it made limited progress with structural reforms that could have 
curbed government spending and could have reduced the need to raise new revenue. The cost of macroeconomic stabilization was horizontally diffused across the population while noticeable adjustments in structural reforms protected the core interests of PASOK's client groups in the broader public sector. This reform pattern substantiates policy bias in favour of preserving the supply of club goods to client groups, in view of interdependent preferences between PASOK and its affiliated unions: they were both better off following a strategy of policy collaboration in the design of policies and, in cases of initial divergence of preferences, co-optation and mutual compromise. 'Clientelist bias' may also be observed in New Democracy's reform record before the 2009 crisis, this time concerning the protection from liberalization policies of its main body of supporters in professional associations, even though the Greek centre-right party had fewer attachments to public sector unions (Trantidis 2014) and proceeded with the full privatization of the state telecommunications enterprise (OTE) and several banks when it returned to power (2004-2009). Finally, the shrinking of distributional politics during the crisis period may be seen as a key reason behind's PASOK's electoral collapse and New Democracy's relative decline.

Table 4: Interaction between client groups and the patron party

\begin{tabular}{|llll|}
\hline Open confrontation & $\begin{array}{l}\text { Coordination with co- } \\
\text { optation }\end{array}$ & $\begin{array}{l}\text { Contained } \\
\text { confrontation }\end{array}$ \\
Policy & $\begin{array}{l}\text { Austerity measures and } \\
\text { incomes policy by the }\end{array}$ & Austerity measures, & Full privatization and \\
& fiscal policy and partial & comprehensive plan for \\
& party in government & privatization by the & pensions reform by the \\
\hline
\end{tabular}




\begin{tabular}{|c|c|c|c|}
\hline & $(1985-1987)$ & $\begin{array}{l}\text { party in government } \\
(1993-2004)\end{array}$ & $\begin{array}{l}\text { party in government } \\
(1998,2001)\end{array}$ \\
\hline Client-group response & $\begin{array}{l}\text { Internal splits and } \\
\text { confrontation with the } \\
\text { party in government } \\
\text { followed by defections } \\
\text { of top-level unionists }\end{array}$ & $\begin{array}{l}\text { Implicit collaboration } \\
\text { and co-optation of } \\
\text { unionists by the party, }\end{array}$ & $\begin{array}{l}\text { Clash with the party in } \\
\text { government but with } \\
\text { no defections, leading } \\
\text { to policy compromise }\end{array}$ \\
\hline $\begin{array}{l}\text { Party stance toward its } \\
\text { client groups }\end{array}$ & $\begin{array}{l}\text { Initially intransigent, } \\
\text { with the expulsion of } \\
\text { dissenters coupled with } \\
\text { co-optation of } \\
\text { complacent union } \\
\text { leaders }\end{array}$ & $\begin{array}{l}\text { Sensitive to group } \\
\text { claims and eager to } \\
\text { adjust its policy; co- } \\
\text { optation through career } \\
\text { promotions }\end{array}$ & $\begin{array}{l}\text { Initially intransigent but } \\
\text { later willing to } \\
\text { negotiate and } \\
\text { compromise }\end{array}$ \\
\hline Outcome & $\begin{array}{l}\text { Mutual losses and } \\
\text { abandonment of the } \\
\text { programme later } \\
\text { (November 1987) }\end{array}$ & $\begin{array}{l}\text { Mutual gains } \\
\text { Partial reforms, fiscal } \\
\text { stabilization and mostly } \\
\text { partial privatizations in } \\
\text { which the management } \\
\text { remained under state } \\
\text { control and the } \\
\text { employment privileges } \\
\text { were safeguarded }\end{array}$ & $\begin{array}{l}\text { Compromise on a } \\
\text { watered-down reform } \\
\text { plan followed by 'social } \\
\text { package' concessions to } \\
\text { the unions }\end{array}$ \\
\hline $\begin{array}{l}\text { Impact on the client- } \\
\text { group }\end{array}$ & $\begin{array}{l}\text { Splits in the union: } \\
\text { political isolation of } \\
\text { defectors }\end{array}$ & $\begin{array}{l}\text { Preservation of ties } \\
\text { with the party }\end{array}$ & $\begin{array}{l}\text { Reassertion of relative } \\
\text { autonomy against the } \\
\text { central party }\end{array}$ \\
\hline
\end{tabular}




\begin{tabular}{|llll|}
\hline Impact on the party & Tensions within the & $\begin{array}{c}\text { Smooth implementation } \\
\text { party, overcome by the } \\
\text { abandonment of }\end{array}$ & $\begin{array}{l}\text { Tensions within the } \\
\text { economic programme }\end{array}$ \\
austerity & abandonment of the \\
& initial plan and the \\
& adoption of a \\
& compromised package \\
\hline
\end{tabular}

\section{Conclusion}

Policy-making is shaped by the institutional setting in which they are embedded. Party clients can become members of organizations endowed with resources and institutional autonomy, such as labour unions, and can take collective action to safeguard both the benefits they enjoy by virtue of their membership in the unions and the turf for patronage as individual clients. Compared to the typical framework of government versus interest groups, this hybrid system of interest intermediation has distinct properties. Rent-seeking is internal to a broader party-client network and develops on the basis of recurrent reciprocity there. The context of interactions and negotiations is configured by close ties between client groups and the party. Organized clients have overlapping identities: through the unions, they can demand accountability from the patron over the provision of club goods, but they remain accountable as individual clients for their political behaviour. This strengthens their position as clients compared to the typical patron-client relationship but limits the autonomy of the labour unions they inhabit; how far they can go in contesting policy proposals, especially those that do not directly threaten their status as 
client groups. Clientelist ties favour moderation, mutual accommodation and policy compromise as the optimal strategies for both patron parties and the organized client groups. As a result, the source of resistance to policy-making is found in the key position of client groups at the heart the party system as vital campaign resources for individual patrons and the party as a whole.

The symbiotic relationship between patrons and organized clients also has noticeable implications for policy-making. The government party's autonomy from client groups and its scope to shift social alliances or forge new ones to promote new policies is considerably more limited in a clientelist system than in the typical interest-group framework. A patron party in government values its client groups not merely as voters but also as active members of its broader support network. It must adjust its policies to safeguard their privileges or risk undermining its cohesion and mobilization capacity and triggering defections that could strengthen its political rivals. These considerations introduce a 'clientelist bias' in the design of economic reforms, which is likely to be resilient even under pressing economic conditions and strong international commitments. Yet, unlike social democratic unionism, the nature of concessions to client groups is highly particularistic and fragmented. This means that clientelist bias can include economic policies that diffuse the cost of adjustment across the general population.

Observation of settings outside Greece may also indicate comparable patterns of cooptation and confrontation between clientelist parties and affiliated unions in view of necessitated reforms under an economic crisis, and can trace their political consequences 
(in Latin America and the Caribbean, see George 2003: 9-10, 21-22; Taylor 2004:220). In Latin America, following a strategy of co-optation of labour unions by clientelist parties during a period of protectionist policies, reformist governments faced the dilemma of how to promote deep-cutting structural reforms to deal with the economic crisis. Governments resorted to 'populist' strategies and traditional patron-client relationships in an effort to disentangle from clientelist-corporatist linkages. When Carlos Menem's radical 'all or nothing' reform programme caused a clash with the unions in Argentina, Menem opted for the substitution of labour-union linkages for direct patronage supply to the urban poor and rural constituencies but, despite his second electoral success, this strategy did not prevent his defeat by the left-wing section of his own party during his second term (Ronchi 2007: 13, 16). However, the experience of Argentina also points to the weakened capacity of the hitherto co-opted unions to swiftly and successfully thwart deep-cutting reforms at the onset (Ronchi 2007: 30). The Mexican and the Argentinean cases suggest that populism, charismatic leadership and vertical patronage ties with individual voters (Teichman 1996: 138-145; Ronchi 2007: 6, 23-26, 28) can prolong the political sustainability of policies that hurt organized client groups but cannot prevent, in the longer term, the demise of the parties that pursue them.

Biographical note: Aris Trantidis is a Visiting Lecturer at the Department of Political Economy, King's College London. 
Address for correspondence: Aris Trantidis, Department of Political Economy, King's College London, Room S2.42, Second Floor, Strand Building, Strand Campus, London WC2R 2LS, United Kingdom. Email: aris.trantidis@kcl.ac.uk

\section{ACKNOWLEDGEMENTS}

The author would like to thank Professor Mark Pennington, Professor Michael C. Munger, Professor Andrew Hindmoor and Dr. Stella Ladi and the three anonymous referees for their valuable comments on different versions of this work.

\section{NOTES}

${ }^{1}$ See measurements of party patronage in Greece by Pappas and Assimakopoulou (2012) and Afonso et. al. 2015: 321. See also Lyrintzis 1984; Spourdalakis 1988, Sotiropoulos 1996; Pappas 2003.

2 This article has drawn on various empirical sources, such as press releases and press commentary, political speeches, party manifestoes, policy documents, legislation and economic reports by international organizations, as well as secondary resources such as books and journal articles.

${ }^{3}$ Estimates suggested that by the mid-1980s 89 percent of PASOK members had some kind of connection with the state sector (Sotiropoulos 1996: 62) and that by the early 2000s, more than 200,000 PASOK members served in the broader public sector (Kathimerini, 28/04/2002).

${ }^{4}$ As documented in the press by Nea, 9 January 1989, p.4 and 12 January.1988. p.4.

5 Minister of Economy Papantoniou praised the unions' stance as 'responsible' (Kyriakatiki Eleftherotypia, 29 July 2001).

${ }^{6}$ Eleftherotypia, 3 August 2001 and 7 August 2001.

${ }^{7}$ See Kathimerini, 1 December 2004, and Vima, 15 November 2009 and 30 March 2010.

${ }^{8}$ See Reports of the Governor of Bank of Greece (years: 1995, 1996, 1997, 1998, 1999, 2000, 2001), Athens. 


\section{REFERENCES}

Alesina A. and A. Drazen (1991) 'Why are stabilizations delayed', American Economic Review 81(5): 1171-88.

Afonso, A., S. Zartaloudis and Y. Papadopoulos (2015) 'How party linkages shape austerity politics: clientelism and fiscal adjustment in Greece and Portugal during the Eurozone crisis', Journal of European Public Policy 22(3): 315-334.

Auyero, J., P. Lapegna and F. Page Poma (2009) 'Patronage politics and contentious collective action: a recursive relationship', Latin American Politics and Society 51(3): 131.

Bates, R., A. Greif, M. Levi, J. Rosenthal and B. Weingast (eds.) (1998) 'Introduction', in Bates et. al. (eds) Analytic Narratives, Princeton NJ: Princeton University Press, pp. 1-22.

Becker, G. (1983) 'A theory of competition among pressure groups for political influence', Quarterly Journal of Economics 98(3): 371-400.

Boettke, P., C. Coyne and P. Leeson (2005) 'The new comparative political economy', The Review of Austrian Economics 18(3/4):281-304 
Börsch-Supan, A. and P. Tinios (2001) 'The Greek pension system: strategic framework for reform', in R. Bryant, N. Garganas and G. Tavlas (eds) Greece's Economic Performance and Prospects, pp. 361-452, Athens and Washington D.C.: Bank of Greece and The Brookings Institution.

Chubb, J. (1982) Patronage, Power and Poverty in Southern Italy: A Tale of Two Cities, Cambridge: Cambridge University Press.

Clifton, J., F. Comín and D. Fuentes (2003) Privatisation in the European Union. Public Enterprises and Integration, Dordrecht: Kluwer Academic Publishers.

Eckstein, H. (2000) 'Case study and theory in political science', in R. Gomm, M. Hammersley, P. Foster (eds) Case Study Method: Key Issues, Key Texts, London: Sage, pp. 119-164.

Eisenstadt, S. N. and L. Roniger (1984) Patrons, Clients and Friends: Interpersonal Relations and the Structure of Trust in Society, Cambridge: Cambridge University Press.

European Commission (1998) European Economy: 1998 Broad Economic Policy Guidelines 66, Brussels: Directorate-General for Economic and Financial Affairs.

European Commission (2000) European Economy: 2000 Broad Economic Policy Guidelines 70, Brussels: Directorate-General for Economic and Financial Affairs. 
Featherstone, K. and D. Papadimitriou (2008) The Limits of Europeanization: Reform Capacity and Policy Conflict in Greece, London: Palgrave Macmillan.

Geddes, B. (1994) Politician's Dilemma: Building State Capacity in Latin America, Berkeley, CA: University of California Press.

George, K. (2003) 'Corporatism and patron-clientelism: a political economy study of development in Mexico and Jamaica', Occasional Paper 20, Latin American Studies Consortium of New England.

George, A. and A. Bennett (2005) Case Studies and Theory Development in the Social Sciences, Cambridge: MIT Press.

Gerring, J. (2004) 'What is a case study and what is it good for?', American Political Science Review 98(2):341-354.

Graziano, L. (1978) 'Center-periphery relations and the Italian crisis: the problem of clientelism', in S. Tarrow, P. Katzenstein and L. Graziano (eds), Territorial Politics in Industrial Nations, New York: Praeger, pp. 290-326. 
Jacoby, W. and M. Behrens (2014) 'Breaking up is hard to do': German trade unions within the Social Democratic Party', Comparative European Politics, doi: 10.1057/cep.2014.29.

Kitschelt, H. (2000) 'Linkages between citizens and politicians in democratic polities', Comparative Political Studies 33(6/7): 845-879.

Kitschelt, H. (2004) 'Political-economic context and partisan strategies in the German federal elections 1990-2002', in H. Kitschelt and W. Streeck (eds.) Germany: Beyond the Stable State, London: Frank Cass, pp. 118-144.

Kitschelt, H. and S. Wilkinson (2007) 'Citizen-politician linkages: an introduction', in H. Kitschelt and S.. Wilkinson, (eds) Patrons, Clients, and Policies: Patterns of Democratic Accountability and Political Competition, Cambridge: Cambridge University Press, pp. 130.

Kitschelt, H., K. Hawkins, J. P. Luna, G. Rosas and E. Zechmeister (2010) Latin American Party Systems, Cambridge: Cambridge University Press.

Krueger, A. (1974) 'The political economy of the rent-seeking society', American Economic Review 64(3): 291-303. 
Landé, C. (1977) 'Introduction: the dyadic basis of clientelism', in S. Schmidt, J. Scott, C. Landé and L. Guasti (eds) Friends, Followers and Factions, pp. xiii-xxxii, Berkeley: University of California Press.

LaPalombara, J. (1964) Interest Groups in Italian Politics, Princeton NJ: Princeton University Press.

Lavdas, K. (2005) 'Interest groups in disjointed corporatism: social dialogue in Greece and European “competitive corporatism”, West European Politics 28(2): 297- 316.

Lyberaki, A. and E. Tsakalotos (2002) 'Reforming the economy without society: social and institutional constraints to economic reform in post-1974 Greece', New Political Economy 7(1): 93-114.

Levi, M. (2002) 'Modeling complex historical processes with analytic narratives', in R. Mayntz (ed.) Akteure, Mechanismen, Modelle: Zur Theoriefähigkeit Makrosozialer Analysen, Frankfurt/Main: Campus Verlag,, pp. 108-127.

Lyrintzis, C. (2005) 'The changing party system: stable democracy, contested “modernisation"”, West European Politics 28(2): 242-259.

Lyrintzis, C. (1984) 'Political parties in post-junta Greece: a case of bureaucratic clientelism', West European Politics 7(2): 99-118. 
Matsaganis, M. (2002) 'Yet another piece of pension reform in Greece', South European Society and Politics 7(3): 109-122.

Matsaganis, M. (2007) 'Union structures and pension outcomes in Greece', British Journal of Industrial Relations 45(3): 537-555.

Mavrogordatos, G. (1997) 'From traditional clientelism to machine politics: the impact of PASOK populism in Greece', South European Society and Politics 2(3): 1-26.

Mcllroy, J. (1998) 'The enduring alliance? trade unions and the making of New Labour, 1994-1997', British Journal of Industrial Relations 36(4): 537-564.

Medina, L. F., and S. Stokes (2007) 'Monopoly and monitoring: an approach to political clientelism', in H. Kitschelt and S. Wilkinson (eds.), Patrons, Clients and Policies: Patterns of Democratic Accountability and Political Competition, Cambridge: Cambridge University Press, pp. 68-83.

Minkin, L. (1992) The Contentious Alliance: Trade Unions and the Labour Party, Edinburgh: Edinburgh University Press.

Mitsopoulos, M. and T. Pelagidis (2011) Understanding the Crisis in Greece: From Boom to Bust, Basingstoke: Palgrave Macmillan. 
OECD (Organization for Economic Co-ordination and Development) (1987) Economic Surveys: Greece, Paris: OECD.

OECD (1992) Economic Surveys: Greece, Paris: OECD.

OECD (2001) Reviews of Regulatory Reform: Regulatory Reform in Greece, Paris: OECD

Pagoulatos, G. (2003) Greece's New Political Economy: State, Finance, and Growth from Postwar to EMU, Houndsmills and New York: Palgrave Macmillan.

Pagoulatos, G. (2005) 'The politics of privatisation: redrawing the public-private boundary', West European Politics 28(2): 358-380.

Pappas, T. (2003) The transformation of the Greek party system since 1951', West European Politics 26(2): 90-114.

Pappas, T. (2009) 'Patrons against partisans: the politics of patronage in mass ideological parties', Party Politics 15(3): 315-334.

Pappas, T. (2014) Populism and Crisis Politics in Greece, Basingstoke, Houndmills: Palgrave Macmillan. 
Pappas, T. and Z. Assimakopoulou (2012) 'Party patronage in Greece: political entrepreneurship in a party patronage democracy', in P. Kopecký, P. Mair and M. Spirova (eds.) Party Patronage and Party Government in European Democracies, Oxford: Oxford University Press, pp. 144-162.

Piattoni, S., (2001) 'Clientelism in historical and comparative perspective', in S. Piattoni (ed.) Clientelism, Interests, and Democratic Representation: the European Experience in Historical and Comparative Perspective, Cambridge: Cambridge University Press, pp. 130.

Pierson, P. (2000) 'Not just what, but when: timing and sequence in political processes', Studies in American Political Development 14(1):72-92.

Ronchi, V. (2007) 'Populism and neopopulism in Latin America' Fondazione Eni Enrico Mattei.

Roniger, L. and A. Güneş-Ayata (1994) Democracy, Clientelism and Civil Society, Boulder CO: Lynne Rienner Publishers.

Schamis H. (1999) 'Distributional coalitions and the politics of economic reform in Latin America', World Politics 51(2): 236-268. 
Scott, J. (1972) 'Patron-client politics and political change in Southeast Asia', American Political Science Review 66(1): 91-113.

Shami, M. (2012) 'Collective action, clientelism, and connectivity', American Political Science Review 106(3): 588-606.

Sotiropoulos, D. (1996) Populism and Bureaucracy: The Case of Greece Under PASOK, 1981-1989, Notre Dame and London: University of Notre Dame Press.

Sotiropoulos, D. (2004) 'The EU's impact on the Greek welfare state: Europeanization on paper?', Journal of European Social Policy 14(3): 267-284

Spanou, C. (2008) 'State reform in Greece: responding to old and new challenges', International Journal of Public Sector Management 21(2): 150 -173.

Spourdalakis, M. (1988) The Rise of the Greek Socialist Party, London: Routledge.

Stokes, S. (2005) 'Perverse accountability: a formal model of machine politics with evidence from Argentina', American Political Science Review 99(3): 315-325.

Stokes, S. (2007) 'Political clientelism.' In C. Bois and S. Stokes (eds), The Oxford Handbook of Political Science, Oxford: Oxford University Press, pp. 602-627. 
Taylor, L. (2004) 'Client-ship and citizenship in Latin America', Bulletin of Latin American Research 23(2): 213-227.

Teichman, J. (1997) 'Neoliberalism and the transformation of Mexican authoritarianism', Mexican Studies 13(1): 121-147.

Tinios, P. (2005) 'Pension reform in Greece: "reform by instalments" - A blocked process?', West European Policy 28(2): 402-419.

Trantidis, A. (2014), 'Reforms and collective action in a clientelist system: Greece during the Mitsotakis administration (1990-93)', South European Society and Politics 19(2): 215-234.

Upchurch, M., G. J. Taylor and A. Mathers (2009) The Crisis of Social Democratic Trade Unionism in Western Europe: The Search for Alternatives, Surrey: Ashgate.

Wantchekon, L. (2003) 'Clientelism and voting behaviour: evidence from a field experiment in Benin', World Politics 55(3): 399-422.

Wilkinson S. (2007) 'Explaining changing patterns of party-voter linkages in India', in H. Kitschelt and S. Wilkinson (eds) Patrons, Clients, and Policies: Patterns of Democratic Accountability and Political Competition, Cambridge: Cambridge University Press, pp. $110-140$. 
